\title{
Research on the Influence of Basketball Culture on College Students' Quality
}

\author{
Yongbo Liu $^{1}$ and Yong Zheng ${ }^{2}$ \\ ${ }^{1}$ School of Physical Education, Chengdu Normal University, Chengdu 610000, China \\ ${ }^{2}$ School of Physical Education, China West Normal University, Nanchong 637009, China
}

Keywords: Basketball culture; physical quality; college students.

\begin{abstract}
The purpose of this paper is to demonstrate the influence of basketball culture on the quality of students in colleges. Colleges are important bases for training talents. Its educational significance is the pursuit of knowledge, scientific and comprehensive development. Meanwhile, the needs of modern society of new high-quality personnel are taken as its purpose. The method is to study the positive guiding role of college basketball culture for the development of students toward scientific, healthy and civilized happiness by logic analysis. The experimental results show that college basketball culture has great influence on improving college students' ideological and moral quality, physical and psychological quality. It also proves that positive basketball culture exerts a subtle influence on the quality of college students through a multidimensional perspective. Based on the above finding, it is concluded that the construction of college basketball culture should set up the cultural concept centered on the needs of college students. At the same time, schools should strengthen the construction of basketball infrastructure in colleges to meet the needs of college students for basketball infrastructure.
\end{abstract}

\section{Introduction}

Culture is the sum of material and spiritual wealth created by human beings in the course of social and historical development. Modern basketball has been introduced into China for more than one hundred years. In the past more than 100 years, basketball has gained wide popularity and development in the world and China [1]. It has changed from the simple competitive games of the past into today's new cultural carriers which include political influence, economic productivity, social affinity and cultural dissemination. Basketball culture refers to the institutionalization of people's way of thinking and behavior in watching and participating in basketball [2]. It is the general name of knowledge, skills, customs and systems of basketball [3]. Its core is the group consensus of basketball values, and its essence is "humanization" and "humanization" of basketball. In May 27, 2005, the Ningbo National Basketball conference, the director of Basketball Management Center of the State General Administration of sport Li Yuanwei stressed: "Chinese basketball in the new period can achieve comprehensive revitalization, fundamentally speaking, basketball culture depends on whether we have the ability to have Chinese characteristics construction and development." Thus, the former people's concept of a single movement of basketball rose to the height of Chinese basketball culture [4].

Previous studies have expounded the connotation, characteristics, essence and function of basketball culture, and discussed the importance of sports to promote the quality of college students [5]. However, there is little research on how to build high basketball culture and promote the quality of college students [6]. College basketball culture is an important part of college sports culture. The construction of basketball culture in colleges has broad ways and spaces for promoting quality education. College basketball culture should take the basketball competition as the breakthrough point, and make it become an important component of quality education [7]. College basketball culture can greatly enrich the campus cultural life, and give full play to the biological, psychological and social multidimensional functions of basketball. It also can improve the comprehensive quality of college students [8]. 
The development of college basketball has become a cultural phenomenon at a certain stage. It has not only the special function of sports, but also the functions and characteristics of culture. Therefore, through analyzing the connotation, characteristics and value of college basketball culture, the influence of college basketball culture on the quality of college students is explored. In addition, the methods and means to build and strengthen the construction of college basketball culture have been put forward, thus enriching the connotation of college basketball culture. This has promoted the diversification of college education and further improved the quality of college students.

\section{Materials and methods}

\subsection{Research Objects}

This paper focuses on the relationship between university basketball culture and college students' quality education.

\subsection{Research Methods}

Through the CNKI search, 251 documents about culture, sports culture, campus culture and basketball culture were collected. Among them, there are 9 theses, and these materials are carefully read, analyzed and arranged, and the current situation of the impact of sports culture on college Students' quality education is grasped. Understanding previous research can broaden our thinking, enrich research materials, and lay the foundation for the smooth progress of this study. It provides a more powerful theoretical basis for the analysis of this paper.

Interviews with 15 educational and sports experts from Beijing Sport University, South China Normal University, and other prestigious universities have been conducted. The purpose of the interview is to better solve the connotation, characteristics and functions of college basketball culture and its influence on the quality education of college students. This is a powerful complement to the literature and investigation. The opinions and suggestions made by experts were carefully analyzed and summarized to ensure the overall and scientific rationality of the study. According to the principle of random sampling, 550 college students from eleven universities in Huaqiao University and Guangxi Normal University were selected as the respondents. The questionnaire includes the influence of the spiritual culture, material culture and system culture of basketball culture on the quality education of college students. Through statistics, the influence of college basketball culture on college students' qualities is obtained. The basic situation of interview experts is shown in the following table:

Table 1. The basic situation of interview experts

\begin{tabular}{|c|c|c|}
\hline & Professional title & Research area \\
\hline Beijing Sport University & 1 professor & Basketball theory \\
\hline $\begin{array}{l}\text { South China Normal } \\
\text { University }\end{array}$ & 1 professor & Sports culture \\
\hline Nanjing University & $\begin{array}{c}1 \text { professor, } 2 \text { associate } \\
\text { professors }\end{array}$ & $\begin{array}{c}\text { Social research methods, social cultural } \\
\text { anthropology }\end{array}$ \\
\hline $\begin{array}{l}\text { Nanjing Normal } \\
\text { University }\end{array}$ & $\begin{array}{l}1 \text { professor, } 1 \text { associate } \\
\text { professor }\end{array}$ & $\begin{array}{l}\text { Social psychology and higher education } \\
\text { theory }\end{array}$ \\
\hline $\begin{array}{c}\text { Jiangxi Normal } \\
\text { University }\end{array}$ & $\begin{array}{l}1 \text { professor, } 1 \text { associate } \\
\text { professor }\end{array}$ & Basketball teaching, sports humanities \\
\hline Wuhan Sports Institute & $\begin{array}{c}1 \text { professor, } 1 \text { associate } \\
\text { professor }\end{array}$ & Sports humanities and social sports \\
\hline Jiangsu Sports Institute & $\begin{array}{l}1 \text { professor, } 1 \text { associate } \\
\text { professor }\end{array}$ & Education, management \\
\hline
\end{tabular}

According to the philosophy of dialectical materialism, the principles and methods of culture, sociology and logic are applied to analyze and study the data. Based on the analysis of the relationship between college basketball culture and the quality of college students, it is concluded that college basketball culture has a positive impact on improving the quality of College students. It puts forward the methods and means to build and strengthen the construction of basketball culture in colleges. 


\section{Research Results and Analysis}

\subsection{Structure of College Basketball Culture}

Structural decision function, so the structure of college basketball culture must be understood in order to study the university basketball culture. Only by knowing the structure of the object can we understand the essence and function of the object, as well as the relation between things and the arrangement and combination of the elements. College basketball culture is the culture headed by ideology. Participants can express all kinds of ideas and ideas through basketball. Basketball rules and regulations are also distinguished from other sports.

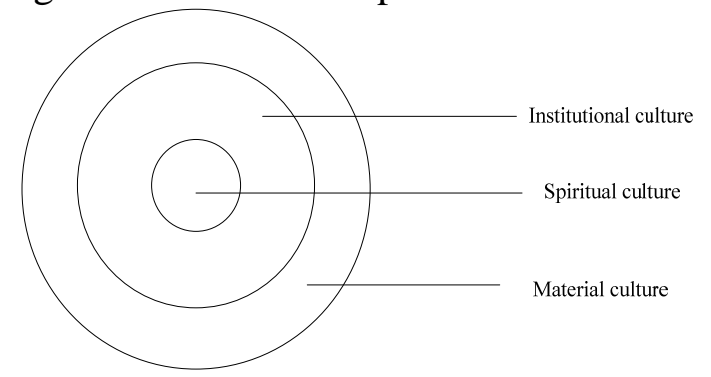

Figure 1. Structure chart of basketball culture

As we know, sports culture in general includes three levels: The psychological elements of sports culture, that is, what we call spiritual culture. It is the ideological, spiritual and conceptual aspects of sports culture. The material elements of sports culture, that is, the material culture. It is the physical level of sports culture. The elements of sports culture, that is, the institutional culture we call it. It is the ways and norms of sports culture. Through the above discussion and analysis, a rough description of the structure of basketball culture is obtained by using deductive reasoning.

\subsection{Analysis for Influence of College Basketball Culture on Physical Fitness}

Physical fitness is a kind of human activity, and it is an important component of physical fitness. At the same time, it is also the basic physical and functional capacity expressed by the body in the exercise of the strength, speed and endurance. The quality of the body directly reflects the people's ability to endure in the normal life. Through investigation and statistics, it is found that college basketball culture has a greater impact on college students' physical quality, and the specific data are shown in table 2.

Table 2. Statistical analysis of the influence of basketball culture on students' physical fitness

\begin{tabular}{|c|c|c|c|c|c|c|c|c|c|c|}
\hline & \multicolumn{2}{|c|}{ Very big } & \multicolumn{2}{c|}{ big } & \multicolumn{2}{c|}{ Medium } & \multicolumn{2}{c|}{ Small } & \multicolumn{2}{c|}{ Very small } \\
\hline & Number & Percentage & Number & Percentage & Number & Percentage & Number & Percentage & Number & Percentage \\
\hline Spiritual culture & 84 & 18.26 & 165 & 35.87 & 127 & 27.61 & 56 & 12.17 & 28 & 6.09 \\
\hline Material culture & 118 & 25.64 & 194 & 42.17 & 113 & 24.57 & 27 & 5.87 & 8 & 1.74 \\
\hline Institutional culture & 70 & 15.22 & 91 & 19.78 & 143 & 31.09 & 88 & 19.13 & 68 & 14.78 \\
\hline
\end{tabular}

By table 2, it is shown that that college basketball spiritual culture has a greater impact on the physical quality of college students. College basketball spirit culture can improve the physical quality of college students by its unique way, instill humanistic spirit and set up its lifelong sports consciousness.

\subsection{Analysis for Influence of College Basketball Culture on College Students' Creative Quality}

In today's society, the development of science and technology is very new, and competition among talents is also fierce. Innovation is the soul of a nation and the inexhaustible motive force of a country's prosperity. Contemporary college students want to succeed in the tide of society, the essential one is innovative. However, it is the important purpose of the creative quality education of college students to cultivate their innovative ability and creative spirit. Culture and innovation must have an inseparable relationship. Without cultural conditions, innovation will become a castle in the air. Through investigation and statistics, it is found that the influence of college basketball culture on the creative quality of college students is weaker than that of 2 :

Table 3. The influence of school basketball culture on students' creative quality

\begin{tabular}{|c|c|c|c|c|c|c|c|c|c|c|}
\hline & \multicolumn{2}{|c|}{ Very big } & \multicolumn{2}{|c|}{ big } & \multicolumn{2}{|c|}{ Medium } & \multicolumn{2}{|c|}{ Small } & \multicolumn{2}{|c|}{ Very small } \\
\hline & Number & Percentage & Number & Percentage & Number & Percentage & Number & Percentage & Number & Percentage \\
\hline Spiritual culture & 56 & 12.17 & 105 & 22.83 & 104 & 22.61 & 98 & 21.30 & 97 & 21.09 \\
\hline Material culture & 65 & 14.13 & 108 & 23.48 & 118 & 25.65 & 98 & 21.30 & 71 & 15.43 \\
\hline Institutional culture & 51 & 11.09 & 68 & 14.78 & 164 & 35.65 & 93 & 20.22 & 84 & 18.26 \\
\hline
\end{tabular}


By table 3, it is concluded that college basketball spirit culture has a general influence on college students' creative quality. The data show that the average number of college students in all the options of "college basketball spirit culture and the innovative quality of college students" is relatively average. This shows that college students believe that the spirit of college basketball culture to improve their quality of innovation in general. The spiritual culture of basketball is a highly innovative culture. It can use the culture function with highly innovative consciousness of college students in mining innovation ability, make students keep a learning attitude of the concept of inheritance and transcendence in other aspects of the study, in the future work full of pioneering spirit.

\subsection{Analysis for the Influence of College Basketball Culture on Students' Aesthetic Quality}

By participating in basketball cultural activities, college students can get a better experience, improve their aesthetic ability and cultivate their aesthetic taste. Marx once said, "when human beings change the objective world, they transform themselves in accordance with the laws of beauty." Contemporary college students are the main force in the construction of the new century. Higher education should improve their aesthetic taste and creative ability through various channels so as to beautify their life. Through investigation and study, it is found that college basketball culture has very weak influence on the aesthetic education of college students. The specific data analysis is shown in table 4:

Table 4. The influence of college basketball culture on college students' aesthetic quality

\begin{tabular}{|c|c|c|c|c|c|c|c|c|c|c|}
\hline & \multicolumn{2}{|c|}{ Very big } & \multicolumn{2}{|c|}{ big } & \multicolumn{2}{|c|}{ Medium } & \multicolumn{2}{|c|}{ Small } & \multicolumn{2}{|c|}{ Very small } \\
\hline & Number & Percentage & Number & Percentage & Number & Percentage & Number & Percentage & Number & Percentage \\
\hline $\begin{array}{l}\text { Spiritual } \\
\text { culture }\end{array}$ & 42 & 9.13 & 50 & 10.87 & 95 & 20.65 & 171 & 37.17 & 102 & 22.17 \\
\hline $\begin{array}{c}\text { Material } \\
\text { culture }\end{array}$ & 52 & 11.30 & 86 & 18.70 & 131 & 28.48 & 139 & 30.22 & 52 & 11.30 \\
\hline $\begin{array}{c}\text { Institutional } \\
\text { culture }\end{array}$ & 38 & 8.26 & 3 & 13.70 & 118 & 25.65 & 194 & 42.17 & 47 & 10.21 \\
\hline
\end{tabular}

As can be seen from table 4, the spiritual culture of college basketball has a very weak influence on the aesthetic quality of college students. There are 42 and 50 people to choose "big" and "very big", accounting for $9.13 \%$ and $10.87 \%$ of the total, respectively. There are 95 people to select medium, accounting for $20.65 \%$ of the total number of college student. There are 171 and 102 people to choose "small" and "very small", accounting for $37.17 \%$ and $22.17 \%$ of the total number of investigators, respectively. It is shown that there is s little percentage about the impact of the spiritual culture on their aesthetic quality, accounting for $20 \%$ of the total number of survey. Only $20 \%$ of college students are considered to be "medium". There is a little people to select "small" and "very small", accounting for $59.34 \%$, which is more than $1 / 2$ of the total number of survey. The election for "small" is the largest number of all options, accounting for $37.17 \%$. The data show that the spiritual culture of college basketball in our country has a weak influence on the aesthetic quality of college students.

\section{Conclusion}

College basketball culture is the institutionalized condensation of the mode of thinking and behavior of college students who watch and participate in basketball in a specific environment. It is the sum of the material, institutional and spiritual culture of basketball. The main participants are contemporary college students, including college students' understanding of basketball, their own basketball concepts, and the university basketball system. Therefore, schools should adhere to the correct orientation of college basketball culture. By means of certain means, the development trend of college basketball culture and the cultural consciousness and cultural behavior of college students will be incorporated into certain normative guidance and operation activities. According to the political, economic, cultural and industrial levels, the concept of "big basketball" in college basketball has been reexamined. The importance of basketball culture in colleges is defined. 


\section{Acknowledgments}

[Project] Sports Culture Research Project of National Sports General Administration; A comparative study of basketball culture between China and America in the global perspective (15TB004)

\section{References}

[1]. Fu, Y., Tang, G., \& Fu, Y. (2015). Integration model of the history and culture of beijing with the quality-oriented education for college students. Journal of Beijing University of Chemical Technology, 15 suppl 5(1), 117-121(5).

[2]. Li, A., Long, J., Tao, G., Chen, Y., \& Wan, S. (2015). Research on the inquiry teaching model of men's basketball teaching in college physical education based on network information technology. International Journal of Smart Home, 9(10), 169-178.

[3]. Ralph, Ann Marie|MacPhail, Ann. (2015). Pre-service teachers' entry onto a physical education teacher education programme, and associated interests and dispositions. European Physical Education Review, 21(1), 51-65.

[4]. Zhang, T., Xiang, P., Gu, X., \& Rose, M. (2016). College students' physical activity and healthrelated quality of life: an achievement goal perspective. Research Quarterly for Exercise and Sport, 87(2), 1.

[5]. Mukhopadhyay, D. K. (2016). Students' perception of quality of medical education in a medical college in west bengal, india. Indian J Public Health, 60(1), 4-9.

[6]. Choi, D. (2015). Physical activity level, sleep quality, attention control and self-regulated learning along to smartphone addiction among college students. , 16(1), 429-437.

[7]. Chen, Y. Y., \& Huang, J. H. (2015). Precollege and in-college bullying experiences and healthrelated quality of life among college students. Pediatrics, 135(1), 18-25.

[8]. Ramaswamy, S. K., \& Mosher, G. A. (2015). Perceptions of agricultural college students on the relationship between quality and safety in agricultural work environments. Journal of Agricultural Safety \& Health, 21(1), 47-64. 